コ一ヒー 飲料について

\title{
Coffee Drinks
}

中 村 賢 一

（中村技術士事務所）

\section{はじめに}

コーヒ一飲料は，ミルク・砂糖入りコーヒーが金属缶 に入った，いわゆる缶コーヒーで代表されるが，最近で はミルクを含まないもの, 無糖のもの, またPET 容器 入りの製品も販売されるよらになり, 容器, 製品とも多 様化されてきている，その消費量も果実飲料を抜き，茶 系飲料，炭酸飲料につぎ，現在，清涼飲料水中第 3 位の 座を占め，社会生活上無視できない存在となっている．

ここではコーヒー飲料の現状を概観し，次いで主要原 材料であるコーヒーとコーヒ一飲料の製造法について述 べ, 最後にこのコーヒ一飲料の食品業界に括ける存在意 義について，この飲料の開発に携わってきた製品開発者 の立場で私見を述べる。

\section{1.コーヒ一飲料の現状}

コーヒ一飲料は，金属缶のほかに紙容器，合成樹脂製 カップ, 最近はPET 容器などの各種容器に入れられて 販売されている。しかし，その容器の約 $90 \%$ は金属缶で ある。

缶コーヒーは1968年に登場してきたが，1970年代後半 から急成長し，その消費量は1997年，2,261,000kl（コ一 ヒ一飲料全体では2, $568,000 \mathrm{kl}$ ) 亿達した。なお，この年 の茶系飲料，炭酸飲料の消費量は，それぞれ3,794,000 $\mathrm{kl} ， 3,006,000 \mathrm{kl}$ であった. 表 $1{ }^{11}$ に, 過去20数年間に 打けるコーヒ一飲料の消費量の推移を炭酸飲料, 果実飲 料, 茶系飲料と共に示した.

コーヒ一飲料の原材料は, 水, コーヒ一, 甘味料, 香 料，界面活性剤であり，これに牛乳や乳製品が加わる場 合と，そうでない場合とがある、牛乳や乳製品が添加さ れた製品はミルク入りコーヒーといわれ，乳成分の添加

本稿は第18回研究集会の発題講演を緾めたものである.
量により，適用される法律が異なる。すなわち, 製品中 の乳含量が乳固形分として $3 \%$ 以上の場合は, 清涼领料 水ではなく乳飲料となり ${ }^{2)}$,「乳及び乳製品の成分規格 等に関する省令」により規制される乳製品となる。した

表 1 コーヒ一飲料の国内消費量の推移（単位1,000kl）

\begin{tabular}{|c|c|c|c|c|c|}
\hline & 炭酸飲料 & 果実飲料 & $\begin{array}{l}\text { 缶入り } \\
\text { ב-七 - } \\
\text { 飲料 }\end{array}$ & $\begin{array}{l}\text { 左のらち } \\
\text { 缶入り } \\
\text { ニーヒー }\end{array}$ & 茶系飲料 \\
\hline 1975 & 2,799 & 903 & 190 & 128 & \\
\hline 1976 & 2,795 & 1,328 & 242 & 193 & \\
\hline 1977 & 3,174 & 1,538 & 313 & 263 & \\
\hline 1978 & 3,408 & 1,821 & 424 & 374 & \\
\hline 1979 & 3,362 & 1,928 & 545 & 495 & \\
\hline 1980 & 2,855 & 1,803 & 620 & 563 & \\
\hline 1981 & 2,668 & 1,810 & 690 & 638 & \\
\hline 1982 & 2,641 & 1,844 & 800 & 750 & \\
\hline 1983 & 2,782 & 1,845 & 938 & 878 & \\
\hline 1984 & 2,894 & 1,913 & 1,073 & 1,013 & 35 \\
\hline 1985 & 2,944 & 1,987 & 1,325 & 1,265 & 177 \\
\hline 1986 & 2,676 & 2,019 & 1,460 & 1,388 & 286 \\
\hline 1987 & 2,771 & 2,238 & 1,648 & 1,575 & 412 \\
\hline 1988 & 2,620 & 2,332 & 1,880 & 1,800 & 585 \\
\hline 1989 & 2,715 & 2,560 & 2,000 & 1,193 & 1,010 \\
\hline 1990 & 2,995 & 2,610 & 2,270 & 2,158 & 1,425 \\
\hline 1991 & 3,040 & 2,402 & 2,500 & 2,202 & 1,685 \\
\hline 1992 & 2,975 & 2,219 & 2,375 & 2,120 & 2,080 \\
\hline 1993 & 2,880 & 2,081 & 2,400 & 2,342 & 2,170 \\
\hline 1994 & 3,162 & 2,135 & 2,415 & 2,211 & 2,779 \\
\hline 1995 & 2,961 & 1,981 & 2,468 & 2,228 & 3,040 \\
\hline 1996 & 2,898 & 1,892 & 2,483 & 2,226 & 3,449 \\
\hline 1997 & 3,006 & 1,814 & 2,568 & 2,261 & 3,794 \\
\hline
\end{tabular}


表 2 公正競争規約によるコーヒ一缶詰の内容物分類

\begin{tabular}{|c|c|c|c|c|}
\hline 項目\分類 & コーヒー入り清涼飲料 & コーヒー入り飲料 & コーヒー & 乳飲料 \\
\hline $\begin{array}{l}\text { コーヒー分 ( } \\
\text { 生豆換算) }\end{array}$ & $1 \sim 2.5 \mathrm{~g}$ 未満 $/ 100 \mathrm{~g}$ & $2.5 \sim 5.0 \mathrm{~g}$ 末満 $/ 100 \mathrm{~g}$ & $5 \mathrm{~g}$ 以上 $/ 100 \mathrm{~g}$ & - \\
\hline カフェイン量 & $10 \sim 25 \mathrm{mg} ※$ & $25 \sim 50 \mathrm{mg} ※$ & $50 \mathrm{mg} \approx$ & - \\
\hline 乳固形分 & $3.0 \%(\mathrm{w} / \mathrm{w})$ 未満 & $3.0 \%(\mathrm{w} / \mathrm{w})$ 末満 & $3.0 \%(\mathrm{w} / \mathrm{w})$ 末満 & $3.0 \%(\mathrm{w} / \mathrm{w})$ 以上 \\
\hline
\end{tabular}

注）昭和 52 年 12 月制定，公正競争規約による

※実測値（公正競争規約には含まれない）

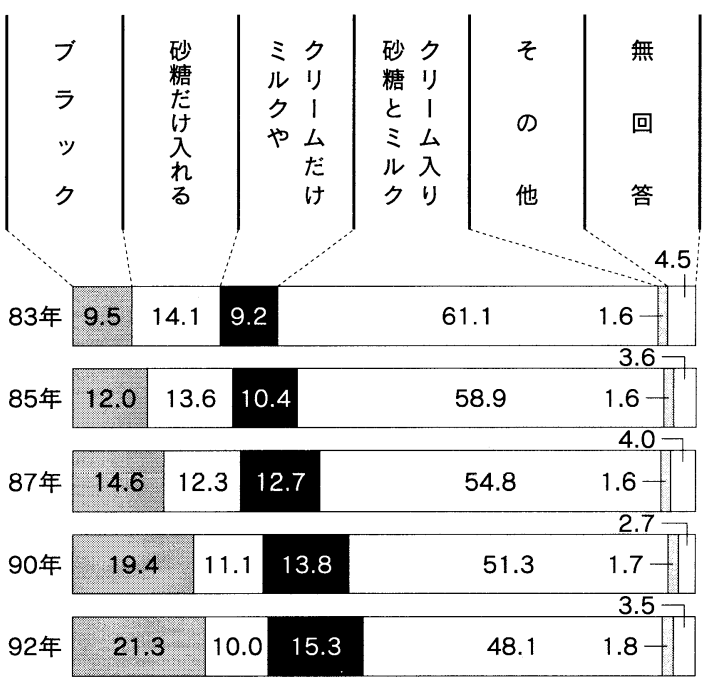

図 1 コーヒーの飲み方

$\lceil 1992$ 年第 6 回調査 : コーヒーの需要動向に関する基本調查」より
がって，コーヒ一飲料を清涼飲料水として製造するため には, 使用する乳量を, 乳固形分として $3 \%$ 未満としな ければならない。ここでは, この清涼飲料水に属するコー ヒ一飲料について述べる.な拈，乳成分を含まないもの はブラックコーヒーと呼ばれているが，その生産量は未 だ非常に少ない。

コーヒー飲料は，「コーヒ一飲料等の表示に関する公 正競争規約」により, コーヒー豆の使用量により, 表 $2^{33}$ に示すように,「コーヒー」,「コーヒー飲料」,「コーヒー 入り清涼飲料」に 3 区分され, 製造, 販売されている. これらの内, 現在, 最も多く消費されているものは「コー ヒー」に区分されるものである.

近年の, 苷さ離市の風潮や健康志向の高まりを反映し てか, 無糖や微糖コーヒーが伸びている. また, 糖類よ りカロリーの少ないあるいはカロリーのない糖アルコー ルや合成甘味料を使用した，いわゆるダイエットコー ヒーも市場に見られるよらになった。一度, 無糖や微糖 のコーヒー飲料を経験すると反復購入する傾向があり, またダイェットに関心のある女性にも受け入れられてい るように思われる。
樹

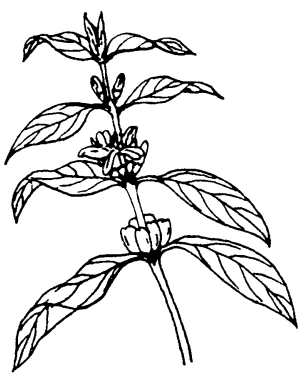

花と果実

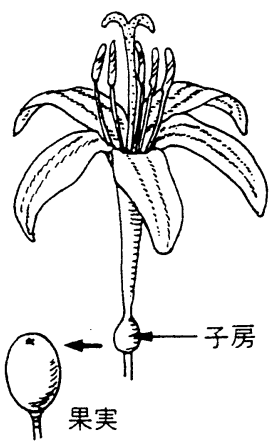

果実とその横断面

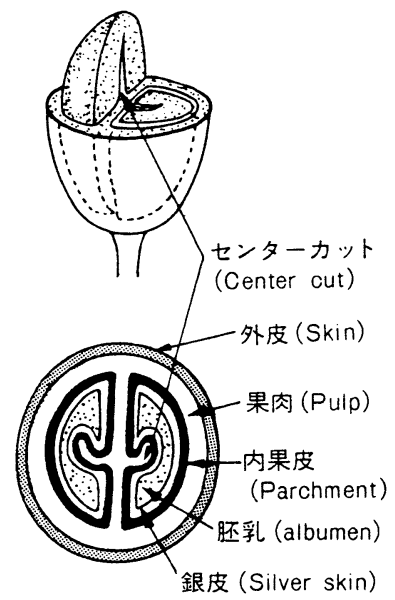

図 2 珈琲の樹，花，果実 
一方，図 $1^{4)}$ に示したよらに，近年のコーヒーの飲み 万は，徐々にではあるが，砂糖やミルクを入れないで， いわゆるブラックで飲导飲み方が増加してきているよう である，この傾向を反映してか，ブラックコーヒーと呼 ばれるミルクを使用していないコーヒー飲料の製品が数 多く市場に見られるようになった。

このよらな傾向が今後も続けば, コーヒー飲料の購買 層の拡大につながり, 結果としてコーヒー飲料の更なる 拡大が期待できる。しかし，その消費量は未だ多くはな い.

\section{2.コーヒー}

コーヒーは，コーヒーの樹の種子を焙って粉を竹湯で 浸出して飲用するものと定義されている5).

コーヒーの樹は, アカネ科 (Rubiaceae)のコフィア属 (Coffea) に属し, 熱帯に自生あるいは栽培される常緑木 本である。その栽培適地は南北回㷌線 の間の熱带地域にあり, この地域を コーヒーベルトまたはコーヒーゾーン とも呼ぶ：通常標高 $200 \mathrm{~m}$ から $1,000 \mathrm{~m}$ の間, 時には $2,000 \mathrm{~m}$ まで栽培される が，他の条件が同じならば標高の高い 汪ど良質のコーヒーが得られるが，制 限標高は霜害の有無による. 現在, 良 質のコーヒーの多くは $1,500 \mathrm{~m}$ 以上の 山の斜面で作られている.

果実は初め緑色であるが，数か月で 黄色く色づき, さらに赤を経て紫がか った深紅に変化する。これはサクラン ボに似ているのでチェリーと呼ばれ る。果実は植物学的には核果で, 中心 部に固い豆（bean）がある，通常は 2 個の半円形の種が向き合って入ってい て, 向き合う面が平らなのでフラット ビーンと呼ばれる.コーヒーの樹, 花, 果実とその断面戍を図 $2^{6)}$ に示した。

この果実（果肉）ょり生豆（green bean）を取り出す処理を精製といい, 水洗式（ウオッシュド, 湿式法) と非 水洗式（アンウオッシュド，乾式法） がある・どちらの方法を採用するかは 精製場所の水の便にかかっている. 一 般的には，水洗式方式によるものは混
入物が少なく，外観は良好であり，品質も均一なので商 品価値は高い。両方式の工程を図 $3^{7)}$ に示した。また， 世界最大のコーヒー生豆生産国であるブラジルにおける 生豆の生産より輸出までの一般的な流通経路を図 $4^{87}$ に 示した。

コフィア属には200以上の品種があり，それらの系統 的な分類は複雑で研究者によっても異なる。しかし，こ れらのらちで商業的に重要なのはアラビカ種, ロブスタ 種, リベリカ種のみである.

市販されているコーヒーの種類は多いが，これは植物 学的分類によるものではなく, 産地あるいは商品学的な 分類であって, 数種のロブスタ種を除いて, ブラジル, コロンビア, モカ, ブルーマウンテン, ガテマラ, マン

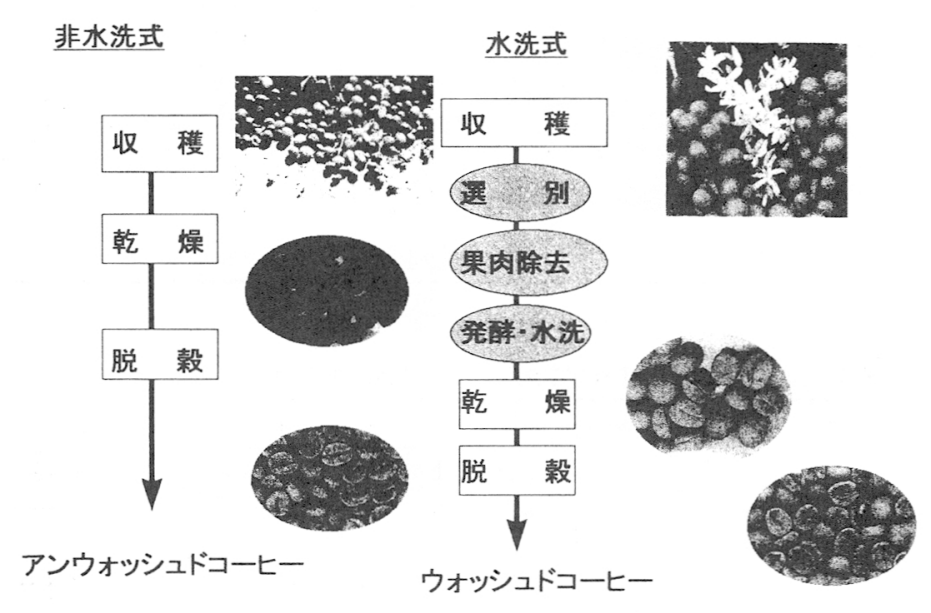

図 3 生豆の処理法

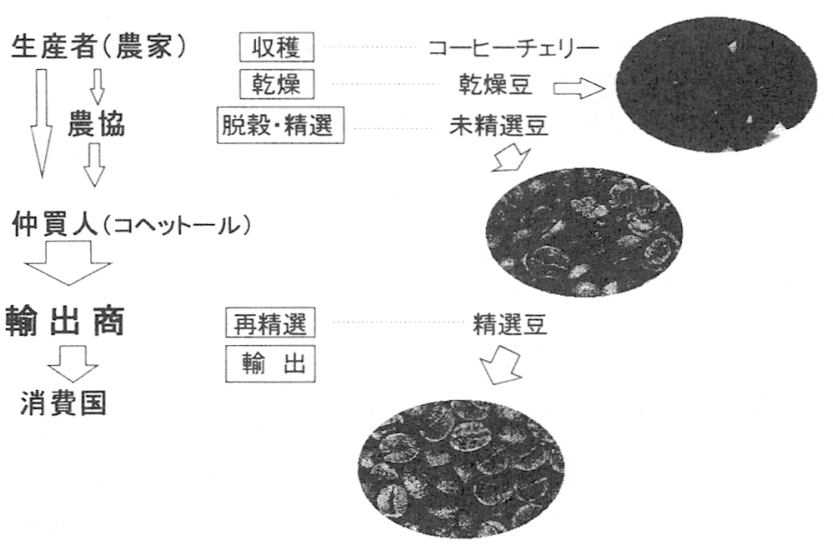

図 4 ブラシルコーヒーの流通（輸出） 
表 3 世界の主要コーヒ一生豆生産国と生産量（単位1000 t )

\begin{tabular}{|c|c|c|c|c|c|c|c|}
\hline 生 産 国 & 1980年 & 1985年 & 1990年 & 生 産 国 & 1980年 & 1985年 & 1990年 \\
\hline 全世 & 4,695 & 5,945 & 5,464 & 南アメリカ & 1,978 & 2,902 & 2,564 \\
\hline アフリカ & 1,178 & 1,232 & 1,204 & ブ ラ シ ル & 998 & 1,919 & 1,441 \\
\hline カメ ル V & 102 & 97 & 100 & コロソビア & 724 & 676 & 801 \\
\hline コートジボアール & 250 & 277 & 219 & エクアドル & 67 & 121 & 129 \\
\hline エチオピア & 187 & 170 & 195 & ペ $ル$ & 95 & 91 & 50 \\
\hline$r=\boldsymbol{T}$ & 91 & 94 & 90 & ベネズェラ & 61 & 64 & 70 \\
\hline マダガスカル & 95 & 82 & 89 & そ の 他 & 33 & 39 & 73 \\
\hline タンザ = ア & 52 & 49 & 58 & ア シ & 591 & 728 & 992 \\
\hline ウガ ン ダ & 123 & 210 & 168 & イ ン ド & 150 & 196 & 118 \\
\hline ザイール & 88 & 92 & 98 & インドネシア & 240 & 313 & 391 \\
\hline そ の 他 & 190 & 161 & 187 & フィリッピン & 145 & 133 & 105 \\
\hline 中央アメリカ & 907 & 1,030 & 1,137 & 夕 & 10 & 24 & 61 \\
\hline コスタリカ & 109 & 155 & 170 & ベトナ & 6 & 8 & 260 \\
\hline ドミニカ (共) & 54 & 72 & 41 & イェ & 5 & 5 & 6 \\
\hline エルサルバドル & 165 & 119 & 156 & そ $\quad$ & 35 & 48 & 51 \\
\hline ガ & 156 & 162 & 210 & オ七ア & 51 & 48 & 67 \\
\hline ホンジュラス & 76 & 75 & 118 & パプアニューギニア & 50 & 47 & 67 \\
\hline ジャマイカ & 1 & 1 & 2 & そ $\quad$ 他 & 1 & 1 & 0 \\
\hline メ キ シ コ & 208 & 308 & 309 & & & & \\
\hline $\begin{array}{lll}= & \text { カ } & \text { ガ } \\
\text { そ } & \text { の } & \text { 他 }\end{array}$ & $\begin{array}{l}55 \\
83\end{array}$ & $\begin{array}{l}50 \\
88\end{array}$ & $\begin{array}{l}43 \\
88\end{array}$ & & & & \\
\hline
\end{tabular}

表 4 コーヒ一生豆の主な化学成分組成（\%無水物中）

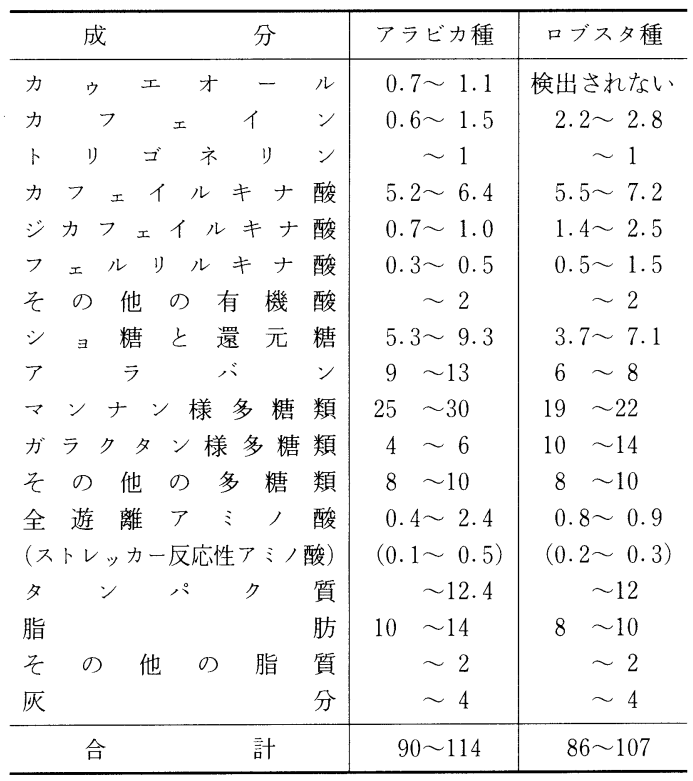

デリンキューバ，ペルー，トラジャなど，それぞれが 特有の香味を持ってはいるが, 何れもアラビカ種である. アラビカ種は世界で栽培されているコーヒーの75～80\%

\section{生豆の質}

\section{婄煎技街}

\section{（配合技術）}

\section{出技很}

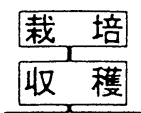

精選処理

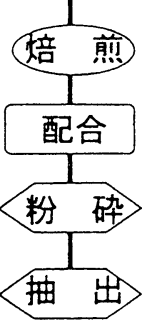

図 5 コーヒーの風味形成

を占め, ロブスタ種が約 $20 \%$, リベリカ種は $1 \%$ 以下と 少ない。表 $3{ }^{9)}$ に世界の主要生豆生産国と生産量を示し た。また，コーヒー生豆の主な化学成分組成を表 $4^{10)}$ に 示した.

コーヒ一飲料を製造する場合，主要原料であるコー ヒーは, (1)焙煎・粉砕したコーヒー豆を購入し, これよ り抽出したコーヒ一抽出液をそのまま使用する場合，(2) コーヒー抽出物の濃縮液を購入し使用する場合, (3)コー 
表 5 コーヒ一豆の品種銘柄別特徴

\begin{tabular}{|c|c|c|}
\hline 品 種 名 & 地 & 味 の 形 \\
\hline$€$ & 了 & 独特な香りとまろやかな酸味とコクがある. \\
\hline ブ ラ シ ル & 南 & 中庸な味, 適度の酸味と苦味があり香りが高い。 \\
\hline コロンビア & " & 甘い香りとまるい酸味とまろやかなコクがある。 \\
\hline ベネズエラ & " & 軽い酸味と適度の香りとやや独特の苦味がある. \\
\hline グマテマラ & 中 & 甘い香り, 上品な酸味, 芳醇な風味をもつ. \\
\hline × キ シ コ & " & 酸, 香りとも適度でやわらかい上品な味がある. \\
\hline 二 ス タリ カ & " & 芳醇な香りと適度の酸味を有し, 上品な味がある. \\
\hline ブルーマウンテン & 西イソド諸島ジャマイカ & 単品で味の調和のよくとれている最高級品. \\
\hline ב & ハワイ島・コナ地方 & 強い酸味と甘い香りがある. \\
\hline 口ブス タ & インドネシアおよびアフリカ & 強い酸味と特異な香りがある. \\
\hline マンデリン & インドネシア・スマトラ島 & コクのあるやわらかな苦味と上品な風味がある. \\
\hline キリマンジャロ & アフリカ・タンザニア & 強い酸味と甘い香りと上品な風味がある. \\
\hline
\end{tabular}

表 6 ブレンドの例

\begin{tabular}{|c|c|c|c|c|c|c|c|}
\hline & $\mathrm{B}^{*}$ & M & $\mathrm{C}$ & $\mathrm{Mn}$ & Gat & Kil & $\mathrm{R}$ \\
\hline \multirow{4}{*}{ 酸味 } & 30 & 30 & 20 & & 20 & & \\
\hline & 30 & 30 & 40 & & & & \\
\hline & 30 & 20 & 30 & & 20 & & \\
\hline & 30 & 25 & 35 & & 10 & & 5 \\
\hline \multirow[t]{4}{*}{ 苦味 } & 30 & & 30 & & & 20 & 20 \\
\hline & 40 & 20 & 20 & 20 & & & \\
\hline & 40 & 20 & 20 & 20 & & & \\
\hline & 40 & 20 & 20 & & & & 20 \\
\hline \multirow{2}{*}{ 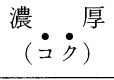 } & 20 & & 40 & 20 & 20 & & \\
\hline & 30 & 20 & 30 & 20 & & & \\
\hline \multirow[t]{3}{*}{ マイルド } & 20 & 30 & 30 & & & & 20 \\
\hline & 40 & 20 & 20 & & 20 & & \\
\hline & 20 & 20 & 20 & 20 & 20 & & \\
\hline オ - ソ & 40 & 20 & 30 & & & & $10 * *$ \\
\hline ドックス & 40 & 30 & 30 & & & & \\
\hline
\end{tabular}

*B:ブラジル(中性小苦) $\mathrm{M}$ :モカ(酸) $\mathrm{C}$ : コロンビア (酸) $\mathrm{Mn}:$ マンデリン(苦) Gat:ガテマラ(酸) Kil:キリマンジャ 口(強い酸，苦） $\mathrm{R}$ : ロブスタ（苦）

**B:C:M:R=40:30:20:10 古くから知られるオーソドックス な配合

\section{表 7 気軽に楽しめる配合の例}

\begin{tabular}{|c|c|c|}
\hline 酸味を好む人向き & 苦味を好む人向き & 甘味を好む人向き \\
\hline コロンビア $30 \%$ & コロンビア $30 \%$ & コロンビア $30 \%$ \\
\hline ブラジル $20 \%$ & ブラジル $20 \%$ & ブラジル $30 \%$ \\
\hline グァテマラ $30 \%$ & グァテマラ $20 \%$ & メキシコ $20 \%$ \\
\hline ジンバブェ $20 \%$ & マンデリン $20 \%$ & 力 $20 \%$ \\
\hline & ジャバロプスタ $10 \%$ & \\
\hline
\end{tabular}

ヒー抽出液の粉末（インスタントコーヒー）を購入し使 用する場合，そして(4)これらを併用する場合とがある。 これらの内で, 品質上の点からか, コーヒ一飲料製造の 場合, (1)のコーヒー抽出液の使用が最も多いようである.

コーヒ一抽出液の製造は, 焙煎·粉砕したコーヒー豆 を焙煎業者より購入し，飲料製造工場で飲料製造時に併 行して行われることが多い. しかし, 近年, コーヒー抽 出粕の処理に苦労することが多くなってきたので，コー ヒー抽出液の濃縮物を購入し使用することの検討もされ 始めている.

焙煎・粉砕したューヒー豆を焙煎業者より購入し自社 で飲料製造時抽出する場合, コーヒー飲料の風味を競合 他社製品と差別化するために，コーヒー豆の配合, 焙煎 度, 粉砕程度, 抽出方法などについて, コーヒー豆供 給・焙煎業者を加えての, 詳細な研究が必要である.こ れはコーヒーの風味の形成が, 図 $5^{111}$ に示したように, コーヒー豆の栽培から抽出までの各過程で, 様々な要因 に影響されるためである.

表 $5^{12)}$ にコーヒー豆の品種銘柄別特徵を示し, 表 $6^{13)}$, 表 $7^{14)}$ にはコーヒー豆の配合割合の例を示した. 表 $8^{15)}$ にはコーヒーの焙煎深度と味の特徴を示した。また，生 豆と焙煎豆の一般成分の比較を表 $9^{16)}$ に示した. 粉砕程 度はコーヒーの香味に影響のあることは勿論であるが， スムースな製造を確保するためには非常に大切な要因あ る. コーヒーの抽出には, 抽出装置, コーヒ一豆の粒度, 抽出温度と水量などの抽出条件により各種の方法がある が，その選択に当たってはコーヒーの香りの品質を第一 
表 8 コーヒーの焙煎（ロースト）深度（岩瀬昌敏, SDT, 1993年 4 号）

\begin{tabular}{|c|c|c|c|}
\hline & 焙 煎 深 度 & & 味 の 特 徵 \\
\hline 浅煎り & ライト（Light） & (極浅炒) & 黄味がかった小麦色. 香り, コクは浅い. \\
\hline$\uparrow$ & シナモン（Cinnamon） & (浅炒) & シナモン色. 香りはやや良い. \\
\hline & ミディアム（Medium） & (中炒) & 栗色. アメリカンスタイルに向いている. \\
\hline & ハイ (High) & (中深炒) & ミディアムよりやや強い炒り方. 香り, 色, 良好. \\
\hline & シティ（City） & (深炒) & $\begin{array}{l}\text { 標準的な炒り方. シティはニューヨークシティに } \\
\text { 由来している. }\end{array}$ \\
\hline & フルシティ（Full City） & (極深炒) & $\begin{array}{l}\text { シティよりやや強い炒り方. アイスコーヒーに向 } \\
\text { いている. }\end{array}$ \\
\hline & フレンチ（French） & （フランス風） & $\begin{array}{l}\text { 焙煎が強く，脂肪が表面ににじみでている．黑く } \\
\text { 独特の香りがあり，カフェオレやウィンナーに向 } \\
\text { いている. }\end{array}$ \\
\hline $\begin{array}{c}\downarrow \\
\text { 深煎り }\end{array}$ & イタリアン (Italian) & タリアン風） & 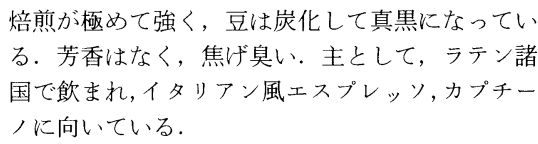 \\
\hline
\end{tabular}

表 9 生豆と焙煎豆の一般成分（\%，無水物中）

\begin{tabular}{|c|c|c|c|c|}
\hline \multirow[b]{2}{*}{ 成分 } & \multicolumn{2}{|c|}{ アラビカ種 } & \multicolumn{2}{|c|}{ ロブスタ種 } \\
\hline & 生 豆 & 焙煎豆 & 生 豆 & 焙煎豆 \\
\hline 全多糖類 & $50.0 \sim 55.0$ & $24.0 \sim 39.0$ & $37.0 \sim 47.0$ & \\
\hline 少糖類 & $6.0 \sim 8.0$ & $0 \sim 3.5$ & $5.0 \sim 7.0$ & $0 \sim 3.5$ \\
\hline 脂質 & $12.0 \sim 18.0$ & $14.5 \sim 20.0$ & $9.0 \sim 13.0$ & $11.1 \sim 16.0$ \\
\hline 遊離アミ，酸 & 2.0 & 0 & 2 & 0 \\
\hline 蛋白質 & $11.0 \sim 13.0$ & $13.0 \sim 15.0$ & $11.0 \sim 13.0$ & $13.0 \sim 15.0$ \\
\hline 全クロロゲン酸 & $5.5 \sim 8.0$ & $1.2 \sim 2.3$ & $7.0 \sim 10.0$ & $3.9 \sim 4.6$ \\
\hline カフェイン & $0.9 \sim 1.2$ & $0 \sim 1.0$ & $1.6 \sim 2.4$ & $0 \sim 2.0$ \\
\hline トリゴネリン & $1.0 \sim 1.2$ & $0.5 \sim 1.0$ & $0.6 \sim 0.75$ & $0.3 \sim 0.6$ \\
\hline 脂肪族酸 & $1.5 \sim 2.0$ & $1.0 \sim 1.5$ & $1.5 \sim 2.0$ & $1.0 \sim 1.5$ \\
\hline 無機成分 & $3.0 \sim 4.2$ & $3.5 \sim 4.5$ & $4.0 \sim 4.5$ & $4.6 \sim 5.6$ \\
\hline 腐植酸 & & $16.0 \sim 17.0$ & & $16.0 \sim 17.0$ \\
\hline
\end{tabular}

に考えて行らべきではないかと考えている.

元来，コーヒーは，茶類と共に人間の水分摂取行動に 対する一つのきっかけになっていることは明白なことで あり，これはコーヒーが持つ効能の一つでもある.これ に加えて, 最近, さらにコーヒ一の抗癌性, 老化抑制（抗 酸化性)などの機能性についての研究が数多く発表さ れ ${ }^{17)}$, 話題となっている. コーヒーと健康に関しては, 中林敏郎・筬島豊等の著書18) に詳述されている.

コーヒーの消費量については各種の統計があるが，表 $10^{19)}$ にコーヒー輸入国別・年次別・一人当たりの年間消 費量を生豆換算量で示した。これによれば，世界的に見
てコーヒーの消費量は横這い, 日本の消費量は, 1997年 で $2.91 \mathrm{~kg}$, この量は世界平均の約 $65 \%$, コーヒー加盟 輸入国22国中15位である。

\section{3.コーヒ一飲料製品と製造方法}

食品衛生法によれば，清涼飲料水は「乳酸菌飲料，乳， 乳製品, アルコール飲料を除くすべての飲料」と定義さ れている ${ }^{20)}$.この見地からコーヒー飲料を見ると，最も 多いミルク入りコーヒ一飲料は, 誠に不思議な飲料であ るといえる。このいわゆる乳製品と乳を含む飲料の住み 分けをしているのが，上述した公正競争規約である。す 
表10 コーヒー加盟輸入国の 1 人当たり消費量推移（生豆換算）

(単位 キログラム)

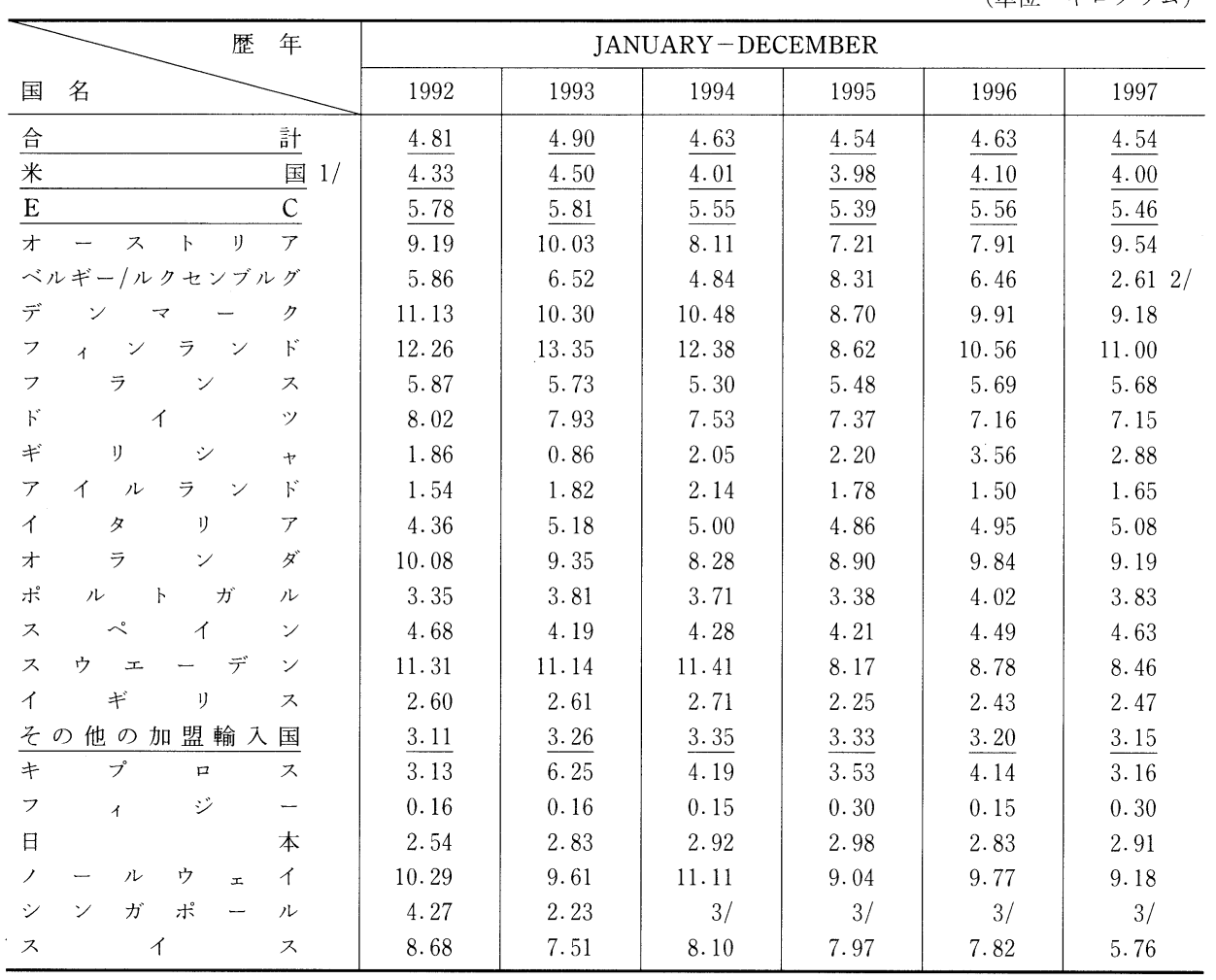

Note : THc data contained in this table are derived from the disappearance in importing Member countries and information on population.

1/ Based on estimates of civilian population by the United States Department of Commerce

2/ Under examination

3/ Re-exports exceeded imports in these years

表11＼cjkstart食品衛生法による清涼飲料水の殺菌基準

\begin{tabular}{|c|c|c|c|}
\hline \multicolumn{3}{|c|}{ 製 造 基 準 } & 保存基準 \\
\hline $\begin{array}{l}\text { 殺菌を要 } \\
\text { しないも } \\
\text { の }\end{array}$ & \multicolumn{2}{|c|}{$\begin{array}{l}\text { 二酸化炭素圧が } 1.0 \mathrm{kgf} / \mathrm{cm}\left(20^{\circ} \mathrm{C}\right) \\
\text { 以上で, かつ, 植物又は動物の組 } \\
\text { 織成分を含まないもの }\end{array}$} & \multirow{3}{*}{$\begin{array}{c}\text { 紙栓をつけた } \\
\text { ガラスびん詰 } \\
10^{\circ} \mathrm{C} \text { 以下 }\end{array}$} \\
\hline \multirow{2}{*}{$\begin{array}{l}\text { 殺 } \\
\text { 菌 } \\
\text { を }\end{array}$} & pH4.0未満 & $\begin{array}{l}65^{\circ} \mathrm{C} \quad 10 \text { 分間 } \\
\text { 同等以上 }\end{array}$ & \\
\hline & $\mathrm{pH} 4.0$ 以上 & $\begin{array}{c}85^{\circ} \mathrm{C} 30 \text { 分間 } \\
\text { 同等以上 }\end{array}$ & \\
\hline $\begin{array}{l}x \\
\text { 要 } \\
\text { す }\end{array}$ & \multirow[b]{2}{*}{$\begin{array}{c}\mathrm{pH} 4.6 \text { 以上 } \\
\text { かつ } \\
\text { 水分活性 } \\
0.94 \\
\text { を超えるもの }\end{array}$} & $\begin{array}{c}85^{\circ} \mathrm{C} 30 \text { 分間 } \\
\text { 同等以上 }\end{array}$ & $10^{\circ} \mathrm{C}$ 以下 \\
\hline $\begin{array}{l}\text { る } \\
\text { も } \\
\text { の }\end{array}$ & & $\begin{array}{l}120^{\circ} \mathrm{C} 4 \text { 分間 } \\
\text { 同等以上 } \\
\text { 発育しらる微生 } \\
\text { 物を存在させな } \\
\text { い方法 }\end{array}$ & なし \\
\hline
\end{tabular}

なわち、コーヒ一飲料には，食品衛生法上，一定量以上 の乳成分を使用し，このため「乳及び乳製品の成分規格 等に関する省令」の規制を受ける製品と，これに該当し ない清涼飲料水の範疇に入るものとがあり，この後者に 入る製品が清涼飲料水であり，食品衛生法の「食品，添 加物等の規格基準 ; D 各条」のうち, 清涼飲料水の項に 従って製造が行われる，ここではこの清涼飲料水に該当 する製品について述べる.

コーヒ一飲料の製品開発は，この法律が規定している 条件をすべて満たすようになされている、コーヒ一飲料 の製造も，食品衛生法で定められている清涼飲料水の製 造基準飞従って行わ机る. 清涼领料水の製造で最も重要 な部分は殺菌処理工程である。この製造基準に上れば， 清涼飲料水の殺菌は，その $\mathrm{pH}$ と水分活性により 3 種類 に分けられ，それぞれについて殺菌条件が定められてい る(表11) 21). 
大部分のコーヒー飲料は，上述のように牛乳成分を含 むので，この飲料の配合終了時の $\mathrm{pH}$ は 7 付近にあり， また水分活性も0.94を超えるので，製造基準の「 $\mathrm{pH} 4.6$ 以上で，かつ，水分活性が 0.94 を超えるもの」に該当し， ここに規定された条件を満足するような殺菌操作がなさ

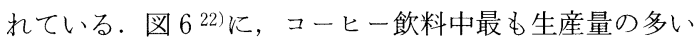
ミルク入り缶コーヒーの典型的な製造工程図を示した.

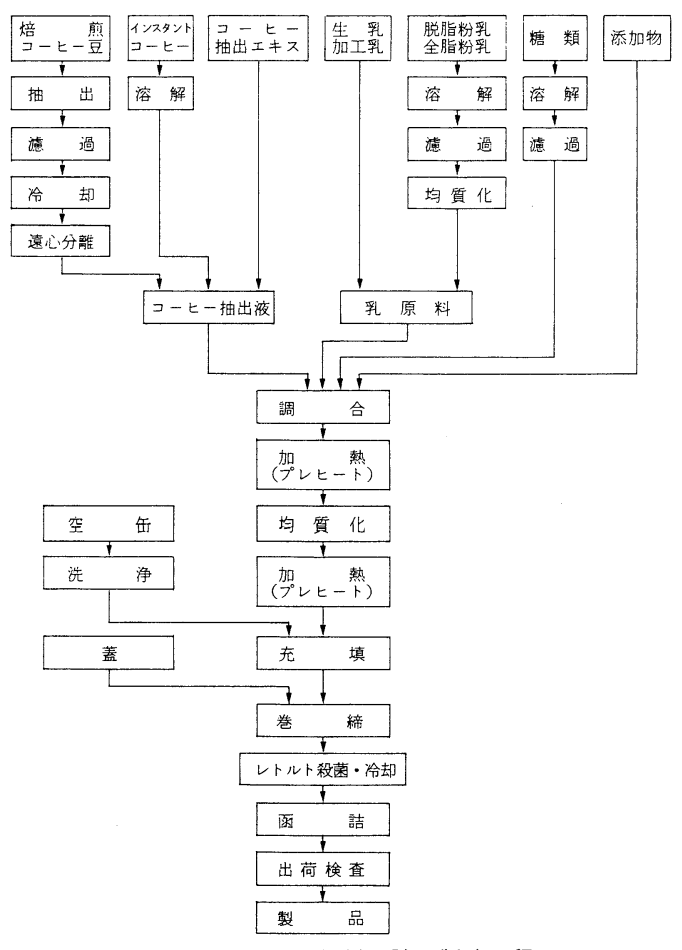

図 6 コーヒ一飲料缶詰の製造工程

この工程中最も注意を要するのは乳原料の混入の工程 で, 乳たんぱくの等電点を考慮して, 乳が投入されるべ き溶液の $\mathrm{pH}$ 調整が必要である.この工程の殺菌はレト ルトでなされているが，その条件は $121 \sim 125^{\circ} \mathrm{C}, 20$ 分内 外が一般的である.

最近, PET 容器を使用した無菌充填方式でミルク入 クコーヒーの製造がなされるよらになった。この方式の 特徵は, 前述のレトルト殺菌方式では飲料を容器に充填 しこれを同時にレトルト内で殺菌するのに対し，無菌充 填方式は飲料と容器を別々に殺菌して無菌的に常温で充 填することである.このため, 無菌充填方式は製品に対 する加熱による熱の影響が非常に少なく, この式で製 造された製品の品質は, 特に香味の点で良好である。し
たがって，コーヒ一豆に由来するコーヒー本来の風味を 製品中に残すための製造方法としては非常に優れてい る、ただ，忘れてはならないことは，この方式の製造方 法が製品のフレーバー保持の点で優れているといらこと は, 殺菌前の製品のフレーバーがそのまま製品中に移行 するといらことであり，使用する原材料の品質に，レト ルト殺菌方式の場合になされた以上の配慮がなされなけ ればならないといらことである。この点に問題があると 思われる製品が時々見受けられるのは，誠に残念なこと である。

コーヒー飲料の製造は, 発売以来約 30 年を経過してい る.この間に経験した製造上，品質管理上の問題につい て，少々ご紹介したい。

先ず最も解決に苦労した問題は, 長期間保存したコー ヒ一飲料中に発生する泥状の僅かな沈殿物である.この 沈殿物を調べてみるとコーヒー中のへミセルロースに $\mathrm{Ca}, \mathrm{Mg}$, カフェイン, タンニンが混在しているもので あることがわかった，そこで，このへミセルロースを分 解寸る酵素の探索から始めた。 その条件は, $20^{\circ} \mathrm{C}$ 以下, 約 2 時間でこのコーヒー中のへミセルロースを可溶化す る能力を持つものであった.かなりの長期間を要したが, 結局, 目的とする酵素を発見し, 製品のフレーバーの劣 化なしに, 製造工程に何らの変更も与えず, 沈殿発生防 止の目的を達成することがでさた.

しかし，最も頭を痛めた問題は，この製品の開発中の ことであったが，製品の出荷管理をどのようにするかで あった. すなわち, 殺菌操作は完壁であっても, 理論的 には無菌にはならないこと, この製品は, 従来から生産 している酸性飲料ではなく中性飲料であり, しかも, た んぱく質を含有していること、したがって, 従来から実 施している出荷管理では, 対応しきれないのではないか といらことであった．種々検討の結果，ある管理システ ムを考光し, これを製品処方にも組み入れ，この製品 の市場導入に踏み切った．これは1975年のことであった が，それ以後現在まで, 大過なく大量生産を続けていら れるのは, もちろん現場の努力に負らところが最大であ るが，われわれの管理システムに誤りがなかったと考え ている次第である.この管理システムは, 現在話題にな っているHACCPの考え方とほとんど同一であること を付言したい。

\section{4. コーヒ一飲料導入の意義}

清涼飲料水の製品開発担当者が常に考えていること は, (1)夏冬の区別なくよく売れる製品の開発，(2)天候の 
影響を受けない商品の開発，(3)清涼飲料水の客層を拡大 できる商品の開発である.

現在, 缶コーヒーを主体とするコーヒ一飲料の状況を 見る之, このコーヒ一飲料は，今や清涼飲料水業界の柱 の一つとなって扣り, コーヒ一飲料の開発は, 清涼领料 水業界に冬場にも売机る商品を提供し，ビジネスに季節 性をなくすことに成功したといえる。

清涼飲料水の製品開発担当者は, (1)の目標を達成した わけであるから，次のターゲットは，(2)の天候の影響を 受けない商品と(3)の客層を拡大できる商品の開発であ る. コ一ヒ一飲料の成功は, この次の開発に, 一つの良 いヒントを与えてくれたと考光ている.

\section{おわりに}

人間の摂水量の調節は, 渴感の有無によりなされてい る. 清涼飲料水の摂取もこの範囲内で行われていると考 光れば，清涼飲料水業界の右肩上がりの成長にも限界が ある. 製品開発者はこの問題への対応を常に考えていな ければならない。この対応の手段のヒントをコーヒ一飲 料の開発の成功によって与えられ，次の(2)及び(3)の開発 の達成が，この問題の解決となるものと確信している.

\section{参考文献}

1）（社）全日本コーヒー協会：コーヒ一関係資料，74（1998 年10月）
2）公正取引委員会 : 飲用乳の表示に関する公正競争規約第 2 条 6 項

3）東洋製罐（株）：飲料缶詰の製造［技術編］29，（1998年 9 月)

4）（社）全日本コーヒー協会：コーヒー\&ヘルス，11

5）小原哲二郎 - 細谷憲政監修：簡明食辞林, 樹村房 (1985)

6) 友田五郎：序説 珈琲学, 28 , (株) 光琳, (1987)

7) 諏訪部英俊：香料 No. 202，57, 日本香料協会 (1999)

8）諏訪部英俊：香料 No. 202，60，日本香料協会（1999）

9）中林敏郎・筬島豊等 : コーヒ一焙煎の化学と技術，13, 弘学出版 (1995)

10）中林敏郎・䇝島豊等：コーヒ一焙煎の化学と技術， 17 , 弘学出版 (1995)

11）諏訪部英俊：香料 No. 202，56，日本香料協会（1999）

12）（社）全日本コーヒー協会：コーヒー関係資料, 133 (1998 年10月)

13）友田五郎：序説 珈琲学, 56, (株) 光琳, (1987)

14）キーコーヒー (株): COFFEE HANDBOOK, 12 (1999)

15）東洋製罐（株）：飲料缶詰の製造［技術編］３0（1998年）

16）中林敏郎・䘬島豊等 : コーヒ一焙煎の化学と技術, 52 , 弘学出版 (1995)

17）第16回国際コーヒー科学会議京都大会（1995年4月9日 ～14日）講演要旨集

18）中林敏郎·筬島豊等：コーヒ一焙煎の化学と技術，163 １82, 弘学出版 (1995)

19）(社）全日本コーヒー協会：コーヒー関係資料, 108 (1998 年10月)

20）厚生省：食品衛生法質疑応答ヘンドブック，284

21）東洋製罐（株）：飲料缶詰の製造［技術編］，128（1998 年)

22）東洋製罐（株）：飲料缶詰の製造［技術編，４4（1998年） 